Journal of Extension Education

Vol. 29 No. 2, 2017

DOI:https://doi.org/10.26725/JEE.2017.2.29.5864-5869

\title{
Communication Behaviour of Farmers Adopting Rice Fallow Pulse Technologies
}

\section{S.Parthasarathi ${ }^{1}$ and A.Shaik Alauddin ${ }^{2}$}

\begin{abstract}
A study was conducted to assess the communication behaviour offarmers adopting recommended rice fallow pulse crop technologies in Karaikal district. Karaikal district is a part of Union Territory of Puducherry located in the tail end of Cauvery delta zone where most of the farmers follow the rice fallow pulse crop with the availabe moisture, which fetches more income to them. The communication behaviour was studied under two dimensions viz., information source utilisation and information sharing behaviour. Correlation was worked out to assess the contribution of communication behaviour in the knowledge and adoption of rice fallow pulse technologies. In the case of regular contact, group members, neighbours and family members were the major sources of information. Information source utilization and information sharing were significant in their relationship with knowledge level of farmers whereas information sharing offarmers alone contributed positively to the adoption of technologies.
\end{abstract}

Keywords : Communication behaviour; Information Source; Mass media; Rice-fallow pulse; adoption; Puducherry

\section{INTRODUCTION}

India is the largest producer, consumer and importer of pulses with a production of 1215 million tonnes in the last two decades. India is facing a severe shortage of pulses since many decades and is dependant heavily on exporting countries. Overall, gaps in technology adoption in major pulse crops both in rainfed and irrigated conditions had been identified. In the case of rice fallow pulse, an important remunerative crop for Cauvery delta farmers, the adoption of recommended technologies is very meagre. Since pulse is a secondary crop in rice fallow pulse cropping system, the farmers were not paying much attention to get the technical support or guidance from their preferred communication sources as in the case of main crops. With this background, in order to strengthen the communication behaviour in order

1. Assistant Professor (Agrl. Extn.) and 2. Professor and Head, Dept. of Agrl. Economics \& Extension, Pandit Jawaharlal Nehru College of Agriculture \& Research Institute (PAJANCOA), Karaikal, U.T. of Puducherry 
to enhance the adoption of recommended technologies, a study was conducted with an objective to assess the communication behaviour of farmers of Karaikal district growing rice fallow pulses.

\section{METHODOLOGY}

The study was conducted in Karaikal district of Union Territory of Puducherry located in the tail end of Cauvery delta region. The respondents were selected from six villages of four communes based on the area under rice fallow pulse crop. From each village, 20 farmers were randomly selected arriving at 120 respondents. The communication behavoiur was studied under two dimensions viz., information source utilisation and information sharing.
Correlation was worked out to assess the contribution of communication behaviour in the knowledge and adoption of rice fallow pulse technologies.

\section{FINDINGS AND DISCUSSION}

The findings of the study are discussed in two sections viz., communication behaviour and its contribution in the extent of knowledge and adoption of rice fallow pulse technology.

\section{Communication Behaviour of Farmers Information Source Utilisation}

The results on the distribution of respondents according to their information source utilisation are presented in Table 1.

\section{Table 1}

\section{Distribution of Respondents according to Information Source Utilisation Behaviour}

$(n=120)$

\begin{tabular}{|c|c|c|c|c|c|c|}
\hline \multirow{3}{*}{ Information Sources } & \multicolumn{6}{|c|}{ Frequency of Contact } \\
\hline & \multicolumn{2}{|c|}{ Regular } & \multicolumn{2}{|c|}{ Occasional } & \multicolumn{2}{|c|}{ Rare } \\
\hline & No. & $\%$ & No. & $\%$ & No. & $\%$ \\
\hline \multicolumn{7}{|c|}{ A. Personal Localite Sources } \\
\hline 1. Family & 40 & 33.33 & 59 & 49.17 & 21 & 17.50 \\
\hline 2. Friends & 33 & 27.50 & 62 & 51.67 & 25 & 20.83 \\
\hline 3. Neighbours & 42 & 35.00 & 54 & 45.00 & 24 & 20.00 \\
\hline 4. Relatives & 23 & 19.17 & 52 & 43.33 & 45 & 37.50 \\
\hline 5. Village Leaders & 34 & 28.33 & 48 & 40.00 & 38 & 31.67 \\
\hline 6. Contact Farmers & 39 & 32.50 & 47 & 39.17 & 34 & 28.33 \\
\hline 7. Trained Farmers & 37 & 30.83 & 41 & 34.17 & 42 & 35.00 \\
\hline 8. Group Members & 45 & 37.50 & 45 & 37.50 & 30 & 25.00 \\
\hline
\end{tabular}




\begin{tabular}{|c|c|c|c|c|c|c|}
\hline \multirow{3}{*}{ Information Sources } & \multicolumn{6}{|c|}{ Frequency of Contact } \\
\hline & \multicolumn{2}{|c|}{ Regular } & \multicolumn{2}{|c|}{ Occasional } & \multicolumn{2}{|c|}{ Rare } \\
\hline & No. & $\%$ & No. & $\%$ & No. & $\%$ \\
\hline \multicolumn{7}{|c|}{ B. Personal Cosmopolite Sources } \\
\hline $\begin{array}{l}\text { 1. Asst.Agriculture Officer/ } \\
\text { Village Extension Worker }\end{array}$ & 12 & 10.00 & 24 & 20.00 & 84 & 70.00 \\
\hline 2. Agricultural Officer & 20 & 16.67 & 26 & 21.67 & 74 & 61.66 \\
\hline 3. NGO & 6 & 05.00 & 27 & 22.50 & 87 & 72.50 \\
\hline 4. Input Agencies & 53 & 44.16 & 23 & 19.17 & 44 & 36.67 \\
\hline $\begin{array}{l}\text { 5. Scientists of Krishi Vigyan } \\
\text { Kendra / PAJANCOA }\end{array}$ & 15 & 12.50 & 39 & 32.50 & 66 & 55.00 \\
\hline \multicolumn{7}{|l|}{ C. Mass Media Sources } \\
\hline 1. T.V & 39 & 32.50 & 51 & 42.50 & 30 & 25.00 \\
\hline 2. Radio & 67 & 55.83 & 48 & 40.00 & 05 & 04.17 \\
\hline 3. Newspaper & 53 & 44.17 & 39 & 32.50 & 28 & 23.33 \\
\hline 4. Leaflets & 19 & 15.83 & 43 & 35.83 & 58 & 48.34 \\
\hline 5. Exhibitions & 23 & 19.17 & 47 & 39.17 & 50 & 41.66 \\
\hline $\begin{array}{l}\text { 6. Posters/Charts/ } \\
\text { Photographs }\end{array}$ & 09 & 07.50 & 29 & 24.17 & 82 & 68.33 \\
\hline 7. Farm Publication & 11 & 09.67 & 30 & 25.00 & 79 & 65.83 \\
\hline \multicolumn{7}{|l|}{ D. Use of Modern Gadgets } \\
\hline 1. Internet & 12 & 10.00 & 20 & 16.67 & 88 & 73.33 \\
\hline 2. Cell Phone & 25 & 20.83 & 32 & 26.67 & 63 & 52.50 \\
\hline 3. Kisan Call Centre & 05 & 04.17 & 06 & 05.00 & 110 & 91.67 \\
\hline 4.CDs/DVDs & 02 & 01.67 & 03 & 02.50 & 115 & 95.83 \\
\hline
\end{tabular}

It could be inferred from Table 1 that the frequency in contacting the personal localite sources of information for pulse technology by majority of respondents was occasional. In the case of regular contact group members $(37.50 \%)$, neighbours (35\%) and family members (33.33\%) were the major sources of information. Regarding personal cosmopolite sources of information, input agencies (44.16\%) were regularly contacted for information. Radio was the most preferred source
$(55.83 \%)$ of mass method among the pulse growers followed by newspaper and TV. Table 1 further reveals that the utilisation of modern ICT gadgets was found to be minimal for access of information related to rice fallow pulse crop. Rice fallow pulse is considered as a secondary crop which required less input and management techniques. Hence, the farmer might have been reluctant in accessing various sources in adopting rice fallow pulse technology. 


\section{Overall Information Source Utilisation}

The results on distribution of respondents according to their overall information source utilisation pattern showed that nearly half $(45.00 \%$ \& $40.00 \%)$ of the farmers had low and medium level of information source utilisation, whereas only 15.00 per cent of the farmers fell under high category. Farmers might have had poor access to information through various sources viz., extension personnel, scientists, NGOs, private companies, ICT gadgets for growing pulse crop, since it is widely perceived as an additional crop.

\section{Information Sharing}

The results on distribution of respondents according to their information sharing is presented in Table 2.

Table 2

\section{Distribution of Respondents according to their Information Sharing}

$(\mathrm{n}=120)$

\begin{tabular}{|c|c|c|c|c|c|c|c|}
\hline \multirow{3}{*}{$\begin{array}{l}\text { S1. } \\
\text { No. }\end{array}$} & \multirow{3}{*}{ Receivers } & \multicolumn{6}{|c|}{ Type of information* } \\
\hline & & \multicolumn{2}{|c|}{$\begin{array}{c}\text { Varietal } \\
\text { Selection }\end{array}$} & \multicolumn{2}{|c|}{$\begin{array}{c}\text { Management } \\
\text { practices }\end{array}$} & \multicolumn{2}{|c|}{ Market } \\
\hline & & No. & $\%$ & No. & $\%$ & No. & $\%$ \\
\hline 1. & Friends & 70 & 58.33 & 31 & 25.83 & 78 & 65.00 \\
\hline 2. & Family Members & 35 & 29.11 & 22 & 18.33 & 49 & 40.81 \\
\hline 3. & Neighbours & 42 & 35.00 & 34 & 28.33 & 44 & 36.67 \\
\hline 4. & Village Leaders & 89 & 74.17 & 71 & 59.16 & 80 & 66.67 \\
\hline 5. & Relatives & 32 & 26.67 & 31 & 25.83 & 29 & 24.16 \\
\hline 6. & Group members & 90 & 75.00 & 81 & 67.50 & 89 & 74.17 \\
\hline 7. & $\begin{array}{l}\text { Participants of agricultural } \\
\text { meetings }\end{array}$ & 92 & 76.67 & 85 & 70.83 & 80 & 66.67 \\
\hline 8. & Officials / Scientists & 35 & 29.17 & 40 & 33.33 & 32 & 26.67 \\
\hline
\end{tabular}

(* Multiple Responses)

The results presented in Table 3 reveal that a majority of the respondents were sharing varietal selection and management practices in agricultural meetings (76.67 \% and $70.83 \%$ ), among group members $(75.00 \%$ and $67.50 \%)$ and with village leaders $(74.17 \%$ and $59.16 \%)$. Sharing of market information was found predominantly among group members $(74.17 \%)$. This shows that their preference in information sharing among the farmers was confined to 
localite sources. The possible reasons for the above findings might be due to the use of own seeds by the farmers and satisfaction with their routine regular practices.

\section{Overall Information Sharing}

The results on distribution of respondents according to overall information sharing behaviour show that nearly two-thirds $(68.30 \%)$ of the farmers shared information to a medium level, whereas 20.00 per cent of farmers fell under high category. This indicates that the farmers show poor interest to share these pulse technologies among their contacts.

\section{Relationship of Communication Behaviour with the Knowledge and Adoption of Pulse growers on Recommended Technologies.}

Zero order correlation was computed to know the contribution of communication behaviour on knowledge and adoption of pulse growers on recommended technologies. The results are given in Table 3.

Table 3.

Zero order Correlation of Communication Behaviour with Knowledge and Adoption of Pulse Growers on Recommended Technologies

\begin{tabular}{|c|l|c|c|}
\hline \multirow{2}{*}{ S1.No. } & \multicolumn{1}{|c|}{ Variables } & \multicolumn{2}{|c|}{$\mathbf{r}^{\prime}$ values } \\
\cline { 3 - 4 } & \multicolumn{1}{|c|}{ Knowledge } & Adoption \\
\hline 2. & Information Source Utilization & $0.5422^{*}$ & $-0.2828 \mathrm{NS}$ \\
\hline
\end{tabular}

(NS - Non Significant, * Significant at $0.02 \%$ level )

A cursory look at Table 3 shows that, 'information source utilization' and 'information sharing' were significant in their relationship with knowledge level of pulse growing farmers. The correlation values were found to be positive and contribute to the extent of knowledge. From this, it might be concluded that those farmers with more of information access could have possess more knowledge on recommended pulse technologies.

In the case of adoption, information sharing of farmers showed a positive and significant relationship. Interest in receiving the information and making use of it in their fields and sharing with fellow villagers might have resulted in a positive correction.

\section{CONCLUSION}

The communication behaviour of farmers might vary according to the crops grown. Rice fallow pulse is a relay crop in Cauvery delta zone which gives more remuneration than the main crop on many occasions. The results of the study showed that still farmers are relying on 
personal localite channels and mass media channels like radio and TV. Little or no use of ICT gadgets was observed. If the farmers are to be made to pay more attention to the cultivation for rice fallow pulses, they need to be made aware of the importance of improving the pulse productivity, utilizing the cosmopolite channels of communication.

\section{REFERENCES}

Hossain, K.Z., Islam, M.R., Bhuiyan, M.H., Wazed. M.A \& Rahman, M.M. (2011). Farmers' Communication Behavior in Receiving Information on Improved Rice production Technologies, Journal of Innovation and Development Strategy 5(1), 28-33 